Павліщук О. П., к.е.н., доцент

Кравець П. В., к.с.-г.н., доцент Домашовець Г. С., к.с.-г.н., доцент Національний університет біоресурсів і природокористування Украӥни м. Київ, Украӥна

DOI: https://doi.org/10.30525/978-9934-26-107-7-16

\title{
ПЛАНУВАННЯ ЛІСОГОСПОДАРЮВАННЯ: СТАН ТА НАПРЯМИ УДОСКОНАЛЕННЯ В КОНТЕКСТІ ВІДПОВІДАЛЬНОГО ВЕДЕННЯ ГОСПОДАРСТВА
}

Планування, як одна із функцій управлінської діяльності, полягає у визначенні цілей та завдань діяльності підприємств лісового господарства, а також способів та засобів їх досягнення. На етапі планування закладають основи відповідального 74 
лісогосподарювання, визначаючи екологічні, економічні та соціальні пріоритети діяльності, формуючи відповідні процеси в рамках охорони, захисту, збереження, відтворення та використання лісів. Можливість коригування планової діяльності та іï провадження відповідно до результатів оцінювання ефективності системи ведення лісового господарства сприяє врахуванню динамічності зовнішнього середовища, зокрема, глобальних екологічних викликів.

Стратегічний рівень планування на підприємствах лісового господарства представлений передусім матеріалами лісовпорядкування, на основі яких розроблено Проєкт організації та розвитку лісового господарства. Зазначений Проєкт є 10-річним планом, в якому з-поміж іншого обгрунтовано напрями організації i розвитку лісового господарства підприємства, наведено заходи з лісокористування.

Елементом як стратегічного, так і інших видів планування $є$ оцінювання впливу на довкілля задля запобігання йому шкоди, забезпечення охорони, раціонального використання і відтворення лісових ресурсів. Висновком 3 оцінки впливу на довкілля, при підготовці якого беруть до уваги звіт з оцінки впливу на довкілля та звіт про громадське обговорення, відповідно до законодавства України визначають допустимість чи обгрунтовують недопустимість провадження планованої діяльності підприємством лісового господарства, а також визначають екологічні умови iii провадження [1].

Елементами тактичного рівня планування на підприємствах лісового господарства є передусім річні плани, наприклад, фінансовий план, виробничо-фінансовий план по лісовому i мисливському господарству та охороні навколишнього природного середовища та інші види планів. Так, у виробничофінансовому плані у розрізі різних заходів (охорона лісу від пожеж, боротьба зі шкідниками та хворобами лісу, лісовідновлення, різні види рубок тощо) наводять обсяги робіт, їхню вартість, а також витрати із зазначенням їхніх джерел. 
Оперативне планування на підприємствах лісового господарства здійснюють на основі планів вищого рівня (тактичних, стратегічних). Зміст оперативного планування діяльності полягає у визначенні на короткі періоди часу (місяць, декаду, тиждень, добу, зміну) конкретних завдань та забезпеченні їхнього виконання. Календарне планування та диспетчерське регулювання виробництва є складовими планування на цьому рівні.

Отже, аналіз практики планування лісогосподарювання в Україні свідчить про багаторівневість цього процесу, зокрема, його представленість різними плановими документами на стратегічному, тактичному та оперативному рівнях. Такі документи охоплюють економічні, екологічні та соціальні аспекти лісогосподарювання відповідно до напрямів діяльності підприємства, але поза увагою залишаються окремі підходи та складові планування, актуальні за сучасних умов зростання глобальних загроз.

У зазначеному вище контексті слід наголосити, що система планування на підприємствах лісового господарства має бути орієнтована на забезпечення екологічно збалансованого, економічно ефективного та соціально корисного лісогосподарювання. Це зумовлює підходи до реалізації цієї функції на підприємствах лісового господарства, зокрема, в частині обов'язкових елементів планування, його гнучкості, адаптивності та ризик-орієнтованості.

Наприклад, вимогами лісової сертифікації - інструменту забезпечення відповідального ведення лісового господарства - в частині планування лісогосподарювання, визначено низку обов'язкових елементів плану ведення господарства. Зокрема, відповідно до FSC національного стандарту системи ведення лісового господарства (надалі - FSC національний стандарт для України) [2], у плані лісогосподарювання мають бути враховані результати оцінювання цінностей довкілля поряд із іншими соціальними, економічними і культурними ресурсами, а також результати оцінювання ризику для них. Елементами плану ведення господарства, 3-поміж інших, мають бути програми та види 
діяльності щодо: гігієни та безпеки праці працівників; стосунків із громадами та місцевого соціально-економічного розвитку; залучення зацікавлених сторін до прийняття рішень. Невід'ємною складовою планування згідно із FSC національним стандартом для України мають бути заходи зі збереження та відновлення: рідкісних видів та тих, що перебувають під загрозою, та оселищ; водних об'єктів і узбережних зон; репрезентативних ділянок аборигенних екосистем; особливих цінностей для збереження. Заходи 3 оцінювання, запобігання та пом'якшення негативних впливів діяльності у плані ведення господарства мають стосуватись як цінностей довкілля, так і соціальних цінностей. Такий запобіжний підхід, реалізований у стандарті, спрямований на попередження небажаних наслідків для довкілля.

Зміни клімату та інші чинники визначають необхідність адаптивного ведення лісового господарства, за якого періодичне оновлення процесу планування має відбуватись на основі результатів моніторингу досягнення цілей та завдань підприємства, а також його екологічних i соціальних впливів. Забезпечення такого моніторингу потребує розуміння сутності та процедури його проведення із охопленням тих обов'язкових складових, які узгоджуються із пріоритетами відповідального лісогосподарювання [3].

Ризик-орієнтованість у плануванні ведення господарства слід розглядати загалом у контексті менеджменту ризиків у системі прийняття рішень. Такий процес відповідно до стандарту ISO 31000 «Менеджмент ризиків. Керівні вказівки» передбачає систематичне застосування відповідних процедур та практик щодо встановлення контексту ризиків, їхнього аналізу, оцінювання, моніторингу та документування [4].

В контексті відповідального ведення лісового господарства саме ризик-орієнтований підхід у плануванні сприятиме попередженню як негативних впливів діяльності на довкілля, так і запобіганню порушень у правозастосуванні. Наприклад, складовою концепції менеджменту ризиків у FSC національному стандарті для України є систематичне оцінювання корупційних 
ризиків підприємства задля запобігання порушенням його антикорупційної політики та відповідно антикорупційного законодавства. Провадження багатьох видів діяльності відповідно до вимог стандарту також визначають масштабом, інтенсивністю та їхнім ризиком [2].

Отже, задля забезпечення відповідального ведення лісового господарства в Україні, отримання довготривалих екологічних, економічних і соціальних ефектів система планування лісогосподарювання має зазнати трансформацій у напрямі посилення тими складовими, які сприятимуть іiі більшій адаптивності до сучасних умов глобальних викликів, іiі гнучкості та ризикорієнтованості. Важливим є посилення бізнес складової у плануванні, що полягає у реалізації конкретних проєктів, спрямованих на забезпечення екологічно збалансованого, економічно ефективного та соціально корисного лісогосподарювання. Зазначені та інші трансформації в системі планування вимагають управлінських рішень з урахуванням системного та адаптивного підходів. Корисним для цього буде досвід системи планування ведення господарства, реалізований в FSC національному стандарті для України, що не суперечить чинній системі планування в Україні, а сприятиме іiі доповненню та поліпшенню задля забезпечення відповідального ведення лісового господарства.

\section{Лiтература:}

1. Про оцінку впливу на довкілля : Закон України від 23.05.2017 p. № 2059-VIII. URL: https://zakon.rada.gov.ua/laws/show/2059-19 (дата звернення: 22.06.2021).

2. FSC національний стандарт системи ведення лісового господарства для України. URL: https://ua.fsc.org/ua-ua/nasha-diyalnist/-07 (дата звернення: 22.06.2021).

3. Павліщук О.П., Кравець П.В. Екологічна та соціальна відповідальність підприємств лісового господарства України в контексті глобальних викликів. Scientific Collection «InterConf», (54): with the Proceedings of the 3th International Scientific and Practical Conference «Global and Regional Aspects of Sustainable Development» (May 4-5, 2021). Copenhagen, Denmark: Berlitz Forlag, 2021. Pp. 77-80. URL: https://interconf.top/documents/2021.05.04-05.pdf (дата звернення: 22.06.2021).

4. ISO 31000:2018 «Risk management - Guidelines». URL: https://www.iso.org (дата звернення: 22.06.2021). 